ORIGINAL RESEARCH PAPER

\title{
A CONSUMER'S PERSPECTIVE ON THE ACTIVE ROLE OF ONLINE MEDIA ENDORSEMENT OF FOOD INTEGRITY BY CONNECTING THE ACTORS INVOLVED
}

\author{
DANA GAFIȚIANU ${ }^{\text {ab }}$, DANIELA BORDA ${ }^{\mathrm{a}}$, LOREDANA DUMITRASCU ${ }^{\mathrm{a}}$, ROXANA ADAM ${ }^{\mathrm{c}}$, \\ ANCA IOANA NICOLAU ${ }^{\mathrm{a}^{*}}$
}

\author{
${ }^{a}$ Dunarea de Jos University, 111 Domneasca Street, 800201 Galati, Romania \\ ${ }^{b}$ Ministry of Agriculture and Rural Development, Bucharest, Romania \\ ${ }^{c}$ Național Institute of Statistics, Bucharest, Romania \\ *corresponding author: anca.nicolau@ugal.ro
}

Received on 14 November 2020

Revised on 26 November 2020

\begin{abstract}
The aim of the paper is to analyse the importance of online media when buying food and the consumers' awareness of its involvement in food integrity. Recognizing the importance of online media in daily life, the paper explores the possibility to get consumers more involved, through social media, in food integrity activities. Thus, the goal of the study was to identify the causal relationship between the involvement of food business operators (FBOs), authorities, and consumers, the three main actors in the food chain. It was found that consumers consider themselves responsible, along with authorities and FBOs, for monitoring food integrity, and that they are interested in periodically receiving information on food integrity through online media. Based on confirmatory factor analysis (CFA) and structural equation model (SEM), the results showed a link between involving consumers, FBOs, authorities and the influence of online media, in monitoring food integrity, therefore online media could be capitalized together with conventional practices, in a complementary manner. Authorities and FBOs should provide online media with tools through which consumers could lodge complaints, if necessary, find out information about food chain supervision, and get access to educational and informative materials regarding food integrity. The paper promotes the idea of transforming informed consumers into informal auditors for the food products.
\end{abstract}

Keywords: social media, food business operator, authorities, external auditor, fraud

\section{Introduction}

\section{General considerations}

Food production is aligned with the general tendency of economic globalization and demographic trends, which puts an increasing pressure on the food trade that is becoming more complex and sophisticated. In such a context, the frequency of

https://doi.org/10.35219/foodtechnology.2020.2.09 
finding inadequate food products on the market is currently increasing, and there is also growing awareness of the need to understand and police food crime and fraud. Food fraud was identified as an increasing problem on a global scale with wideranging economic, social, health and environmental impacts (Ellis et al., 2016). More than $€ 100$ million worth of potentially dangerous food and drinks was seized in the VIII Operation OPSON, coordinated by Europol's Intellectual Property Crime Coordinated Coalition and INTERPOL (Europol, 2019). Food fraud was estimated to cost the global food industry $\$ 10-15$ billion per year (Cattini, 2016). Despite the existing laws, regulations, standards, technologies and tools that are targeting the food industry, scandals continue to arise especially when involving non-tangible issues like food integrity (Ali and Suleiman, 2018). Therefore, it can be quite challenging for the consumers to buy the right food due to the rising trend of finding inadequate products on the market.

In recent years the attention paid to food fraud has increased not just at European level, but also worldwide. In this respect, we can mention several initiatives which have been taken, such as:

(i) defining terms as: Food Integrity, Food Fraud, Food Defense, Food Authenticity, Food Crime, Economically Motivated Adulteration, Food Protection (Spink et al., 2019; Manning, 2017) - there are many active institutions: US FDA, Michigan State University, Codex Alimentarius (CODEX), Global Food Safety Initiative (GFSI), European Commission (EC), UK Department for Environment, Food \& Rural Affairs (DEFRA), International Organization for Standardization (ISO);

(ii) setting up databases: US Pharmacopoeia (USP) Food Fraud Mitigation Database, which has been renamed the Food Fraud Database, owned by Decernis, Washington, DC, USA; Food Adulteration Incidents Registry (FAIR) provided by Food Protection and Defense Institute (FDPI) at the University of Minnesota; the Rapid Alert System for Food and Feed (RASFF) database which operates with the EU Administrative Assistance and Cooperation (AAC) system; the Food Fraud Risk Information, which is a free and accessible database on incidences of food fraud and emerging threats; the UK food surveillance system (UKFSS) database; FoodSHIELD, HorizonScan (Manning and Soon, 2019);

(iii) setting up international cooperation on projects (consortia) or actions: "Food Integrity", "MoniQa" and "TRACE" within HORIZON 2020 (Danezis et al., 2016), INTERPOL Operation Opson;

(iv) developing questionnaires and guidelines to identify fraud vulnerabilities, as organizations like the Grocery Manufacturers Association (GMA) in the US, the British Retail Consortium (BRC), the European Spices Association (ESA), Safe Supply of Affordable Food Everywhere (SSAFE) have been created. The Department for Environment, Food \& Rural Affairs (DEFRA) and the Food Standards Agency (FSA), through PAS 96:2014 initially and then PAS 96: 2017, describe a risk management methodology named Threat Assessment Critical Control Points (TACCP). The USA developed the Food Fraud Initial Screening Model (FFISM) (Spink et al., 2016a) while a number of Governments in the 
Western European countries in particular, but not only, developed structures such as: the National Food Crime Unit (NFCU) in the UK, Intelligence and Investigation Service of the Food and Consumer Products Safety Authority in Holland; BeoWarn and the National Reference Centre for authenticity and integrity in the food chain in Germany, at the Max Rubner-Institute; Food Fraud Flying Squad at the Danish Veterinary and Food Agency; "Pola" tool, a phone application, in Poland. In Romania, in 2015, national and international experts analysed food integrity within the frame of a European project implemented by the Government of Romania and the Ministry of Agriculture and Rural Development - the results were included in a report entitled "Assessment of Food Integrity in Romania" (SGG, 2015).

In this context, the aim of the study was to examine the Romanian consumers' awareness concerning food integrity, related to: (i) who should get involved in order to eliminate /reduce inadequate (unsafe, poor quality, falsified etc.) food products from the market; (ii) reactions towards inadequate purchased food (notifications/complaint forms to the responsible institutions to report deficiencies/irregularities/deviations); (iii) the importance of safety, quality, authenticity and online media when buying food; (iv) the consumers' interest in receiving information about food integrity and their involvement in food integrity activities, in collaboration with authorities and food business operators (FBOs), in order to contribute to the reduction/elimination of non-compliant products from the market; (v) the existence of a causal relationship between the involvement in food integrity activities of consumers, FBOs and authorities and the importance of online media when buying food.

\section{Research hypothesis and conceptual research framework}

Food integrity is a generic and comprehensive term for sound, nutritive, healthy, tasty, safe, authentic, traceable, as well as ethically, safely, environment-friendly, and sustainably produced foods (Elliott, 2012).

Ensuring food integrity is a difficult task, not only because of its many facets, but also due to the length and complexity of the global food supply chain and the number of stakeholders involved (Ali et al., 2017; Manning, 2016; Manning, 2017; Ali and Suleiman, 2018). In addition to international and national preventative measures enforced by the in-charge authorities, the responsible media and FBOs must prevent food fraud from occurring (Soon et al., 2019) or, if needed, be prepared to mitigate it. According to the "farm to fork" strategy of the European Commission, consumers have to share responsibilities with FBOs and authorities, and should be well informed and able to communicate with the other participants in the food chain. The Internet has become one of the main sources of food information (Kuttschreuter and Hilverda, 2019; Ma et al., 2017), while social media provide consumers with an easy-to-use tool to communicate with others (Hamshaw et al., 2018), authorities included.

A culture that questions the source of its supply chain in the benefit of food integrity should be encouraged. A growing body of research has already focused on the detection of adulterated food products, establishing targeted analytical 
techniques and tools for identifying vulnerable points in the food supply chain (Soon, 2019).

However, it is acknowledged that consumers are the key drivers of food integrity in the supply chain and their role should be amplified. Based on the fact that family and friends' opinions on food integrity and social media information on food choices are considered reliable sources of information by consumers who try to find insights in food consumption, food preparation and food purchase (Kuttschreuter and Hilverda 2019; Borda, 2020), consumer vigilance via communication channels should be supported by all the parties involved in the food system. This is in accordance with previous studies, where the authors stated that authenticity identification could be operationalised through everyday people (Davis et al., 2019).

Nowadays, with the help of the Internet, consumers are able not only to seek information online, but also to publicly post messages, pictures and videos related to food issues, and to comment on them (Mangold and Faulds, 2009; Kuttschreuter and Hilverda, 2019). Thus, consumers would be able not only to address their most alarming worries and fears, but also to be more accessible for receiving information. In fact, online media could be used as a proper communication tool regarding food integrity, but it should be treated consciously because this very effective two-way avenue for communication has also demonstrated a very fast capacity to react and backfire. For example, when shopping online, how many of us did not check for other people's opinions or comments? This reference to other consumers could help us take the right decision if a product is authentic or a service should be trusted.

Another important advantage of online media is that many frauds that could otherwise remain hidden or get "cold", could rapidly be unveiled by a system able to react in real time and respond to different cues provided by consumers.

(H1) The higher the implication of consumers in online media (Importance of Online Media - IOM) when buying food, the higher the interest in food integrity (INV).

Social media can be an asset to food safety risk communicators, but depending on the context it can be a hindrance, as well (Chapman et al., 2014). The discussions on food safety can very easily turn in the online environment and may lead to a social amplification of risk perception, while, if assessed by technical experts, risks could be considered minor (Chapman et al., 2014; King et al., 2017).

Notably, some authorities have already established strategies to effectively communicate online with consumers. For example, in the US, Centres for Disease Control and Prevention (CDC) have effectively implemented social media platforms in their communication strategies in times of crises (Rutsaert et al., 2014).

The value of using online media by authorities was proven by the use of crowdsourcing in 2011 in the EHEC crisis in Germany, when online forums 
developed by researchers and the World Health Organisation allowed scientists all over the world to feed and provide valuable information for the investigation.

An important initiative was the document released by the European Center for Disease Control and Prevention (ECDC) in 2016, that published A guide to using social media for public health communication, placing emphasis on how to craft a social media strategy (ECDC, 2016). It is a strategic approach on how to engage consumers through social media. However, up to now there has been no report to evaluate how consumers are engaging stakeholders via social media.

In a recent study it was found that Spanish consumers did not show a high overall level of trust in food authorities; regarding the trust in the food value chain, French consumers in general had low levels of trust in all the actors except authorities, while Polish consumers had low levels of trust in authorities (Macready et al., 2020). This could also suggest a low communication flux exchange between consumers and authorities, as better results were observed in places where these channels of communication are up and running, as for example in Norway (ECDC Guide).

The reluctant attitude towards social media experienced by the authorities in the food domain may result from a lack of information on how to effectively incorporate social media into communication strategies. Even if authorities and official bodies may be willing to have a presence on social media they are reluctant to effectively engage in it (Rutsaert et al., 2014), most probably due to denialism, counter knowledge and fake news phenomena that are difficult to stop in online media.

As food fraud was of greater concern to consumers than other types of emerging risks (Afonso et al., 2019), it could be an important driver that should be better integrated in the risk communication work. This integration could be done more easily by authorities via social media channels if the right tools are provided. Thus, it was also hypothesized that:

(H2) There is a positive correlation between food integrity mediated by the participation of consumers in online media and the involvement of the authorities.

"Interpersonal Trust" is related to the trust a consumer has in his provider of food usually a private company or individual - whether that be a supermarket chain, an open market, a local farmer or market stall holder or any other supplier or food producer (Lobb, 2005).

International food companies acknowledged the power of social media and gradually shifted their marketing and communication budgets into new media where the public gets the opportunity for both creating and sharing content.

As a consequence, the company is not holding the total control on the communication that is partly transferred to the online community. The so-called "viral marketing" where customers are encouraged to forward online marketing messages to members of their social network (Van Der Lans et al., 2010; Rutsaert et al., 2014) is a powerful instrument to involve the community and rapidly spread 
the information. This was proven by the campaigns of PepsiCo (2009), "Cadbury Eyebrows" and "Cadbury Gorilla" (2012). The flexibility that a company should have to quickly interact with social media was demonstrated by other successful campaigns, such as Dunk in the Dark by Oreo (2013) when Oreo took advantage of timing during a power outage at Superbowl; a chicken nugget re-tweet challenge by Wendy`s fast-food chain ("A man needs his nuggs"); or virals such as the one produced by Popeye's, a fast-food chicken restaurant that introduced their new chicken sandwich and effectively broke the Internet (Roberts, 2020).

Rutsaert et al. (2014) explored the potential of social media to enforce some of the key principles recommended for effective risk benefit and communication. Their work pointed out that social media applications are particularly useful due to the opportunity of direct communication and interaction with the audience.

However, one should take notice of failed online campaigns, such as the one by Twitter that wanted to engage consumers in talking about their favourite memory of the fast-food chain that backfired when Twitter users "hijacked" the hash tag to tell horror stories of food safety and production and poor service (Bradshaw, 2012).

Conversely, a very interesting example is the effort of FBOs to involve consumers into the co-creation of new food products, as applied by Barilla (Martini et al., 2014).

It is worth mentioning that notifying consumers on food integrity aspects by FBOs via marketing campaigns that could later be converted into virals is not yet a reality, but considering the importance of online media in the post-CoViD times the role of influencers is expected to increase (Goyal, 2020) and FBOs should take advantage of this aspect, using the right tools out of these new communication channels.

(H3) There is a positive correlation between food integrity mediated by the participation of consumers in online media and the involvement of the FBOs.

It is paradoxical that although consumers are recognized as the first pillar of food integrity, they often ignore or query the risk assessments and advice of scientists, the food industry and/or public bodies. However, informed consumers can effectively change this by holding responsible all other actors and themselves.

The role of influencers is also significant for the consumers present in online media. Although influencers most often neither possess a background in food safety nor in food science, they have an expanding role in influencing public perceptions (Byrd-Bredbenner et al., 2015; King et al., 2017).

Deterrence of food crime starts with consumer awareness and encouraging consumers to have a voice and react; it could be a very effective way to ensure food integrity. In fact, each consumer should be viewed as a food integrity auditor in the market, and playing an active role would directly make him/her engaged in counterfeits elimination. If all consumers are connected via online media and they are informed, some of the fraudulent activities could be rendered futile. However, to actively engage in meaningful activities, consumers should be trained, educated 
and have accurate knowledge. Thus, early education in food integrity is of paramount importance (Wang et al., 2017).

Overall, it will be important for consumers`organizations and food safety professionals to be proactive in creating and maintaining social media channels and means of disseminating food safety and integrity information in a targeted manner to seek discussion and educate the media and consumers (King et al., 2017).

(H4) There is a positive correlation between food integrity mediated by online media and the involvement of the consumers in reporting food adulteration / fraud / crime.

\section{Materials and methods}

\section{Consumer survey}

A survey was conducted to reveal the Romanian consumers' involvement in social media. The questionnaire was created, tested and validated between December 2018 and January 2019, while the responses were collected from February to April 2019. The survey was divided into two parts: the first part was related to demographic variables (age, gender, level of education) and the second part had four sections comprising questions related to food consumers' belief about: the importance of reactivity in media (4 items), the necessity of FBOs involvement in social media ( 3 items), the necessity of the authorities` involvement in social media (4 items), the importance of social media when buying food ( 3 items). The consumers' belief regarding their involvement in food integrity aspects (CINV), the consumers' belief regarding the FBOs involvement, through online media, in food integrity aspects (PINV), and the consumers' belief regarding the authorities' involvement, through online media, in food integrity aspects (AINV) were measured based on a Likert scale, ranging from 1 - strongly disagree to 10 strongly agree, whereas the importance of online media when buying food (IOM) was measured based on a Likert scale, with 5 variants of responses (from 1 - not at all to 5 - very important) (Table 1 ).

The questionnaire design and testing involved the verification of the way of understanding, interpretation and acceptability of the formulated questions, considering that most of the respondents do not master the specialized technical language. The exploratory research was conducted: (i) via an online platform of surveys and distributed by email to various institutions and (ii)by direct dissemination and collection of questionnaires. The questionnaire was addressed to respondents residing in Romania, in Romanian and administered on a self-reported base.

As a result, 190 questionnaires were validated and used for data analysis. The Cronbach's alpha coefficient was calculated to demonstrate the reliability of the construct, 0.6 being considered the threshold value for good internal consistency.

\section{Statistical analysis}

Based on the 190 validated questionnaires, a descriptive analysis was conducted, followed by a two-step modelling (Kline, 2011): the confirmatory factor analysis 
(CFA) was tested first, followed by a full structural equation model (SEM). The CFA and the SEM were constructed according to a proposed theoretical model using R software, "lavaan" package.

Table 1. Measured items and the scale for rating latent and observed variables.

\begin{tabular}{|c|c|c|c|c|}
\hline $\begin{array}{c}\text { Latent } \\
\text { variable }\end{array}$ & $\begin{array}{c}\text { Measured } \\
\text { items } \\
\text { (Statements) } \\
\end{array}$ & Observed variable & Code & $\begin{array}{c}\text { Likert } \\
\text { scale } \\
\text { (min-max) } \\
\end{array}$ \\
\hline \multirow{4}{*}{$\begin{array}{l}\text { Consumers' } \\
\text { opinion } \\
\text { about their } \\
\text { involvement } \\
\text { in food } \\
\text { integrity } \\
\text { aspects } \\
\text { (CINV) }\end{array}$} & \multirow[t]{4}{*}{$\begin{array}{l}\text { Food } \\
\text { consumers } \\
\text { should } \ldots\end{array}$} & $\begin{array}{l}\text { notice / make a complaint when } \\
\text { purchasing a counterfeit / } \\
\text { inauthentic food item }\end{array}$ & Cons_a & $(1-10)$ \\
\hline & & $\begin{array}{l}\text { react / alert, consumer complaints } \\
\text { can help increase the quality / } \\
\text { safety / authenticity }\end{array}$ & Cons_b & $(1-10)$ \\
\hline & & $\begin{array}{l}\text { know, learn more about food } \\
\text { integrity }\end{array}$ & Cons_c & $(1-10)$ \\
\hline & & $\begin{array}{l}\text { take part in monitoring/ } \\
\text { identification of counterfeit }\end{array}$ & Cons_d & $(1-10)$ \\
\hline \multirow{3}{*}{$\begin{array}{l}\text { Consumers' } \\
\text { opinion } \\
\text { about FBOs } \\
\text { involvement, } \\
\text { through } \\
\text { online media, } \\
\text { in food } \\
\text { integrity } \\
\text { (PINV) }\end{array}$} & \multirow[t]{3}{*}{$\begin{array}{l}\text { FBOs } \\
\text { should ... }\end{array}$} & $\begin{array}{l}\text { provide consumers with the } \\
\text { opportunity to vote/rate their } \\
\text { products based on their own } \\
\text { experience - use of an electronic } \\
\text { voting system }\end{array}$ & Prod_a & $(1-10)$ \\
\hline & & $\begin{array}{l}\text { specify on the label the way of } \\
\text { notifying negative aspects online }\end{array}$ & Prod_b & $(1-10)$ \\
\hline & & $\begin{array}{l}\text { be involved in activities/actions to } \\
\text { inform/educate consumers }\end{array}$ & Prod_c & $(1-10)$ \\
\hline \multirow{4}{*}{$\begin{array}{l}\text { Consumers' } \\
\text { belief about } \\
\text { the } \\
\text { authorities' } \\
\text { involvement, } \\
\text { through } \\
\text { online media, } \\
\text { in food } \\
\text { integrity } \\
\text { aspects } \\
\text { (AINV) }\end{array}$} & \multirow[t]{4}{*}{$\begin{array}{l}\text { Authorities } \\
\text { should ... }\end{array}$} & $\begin{array}{l}\text { provide consumers with the } \\
\text { opportunity to report/ notify } \\
\text { online negative aspects of food } \\
\text { integrity - to ensure a public } \\
\text { platform to this purpose }\end{array}$ & Aut_a & $(1-10)$ \\
\hline & & $\begin{array}{l}\text { use social media to promote food } \\
\text { integrity }\end{array}$ & Aut_b & $(1-10)$ \\
\hline & & $\begin{array}{l}\text { use an IT application to signal / } \\
\text { warn consumers that the product } \mathrm{x} \\
\text { has integrity problems/ } \\
\text { deficiencies }\end{array}$ & Aut_c & $(1-10)$ \\
\hline & & $\begin{array}{l}\text { report-online the results of the } \\
\text { checks carried out at FBOs }\end{array}$ & Aut_d & $(1-10)$ \\
\hline \multirow{3}{*}{$\begin{array}{l}\text { Importance } \\
\text { of online } \\
\text { media when } \\
\text { buying food } \\
\text { (IOM) }\end{array}$} & \multirow{3}{*}{$\begin{array}{l}\text { Importance } \\
\text { of these } \\
\text { factors when } \\
\text { buying food }\end{array}$} & Social media & $\mathrm{SM}$ & $(1-5)$ \\
\hline & & Instagram & INSTA & $(1-5)$ \\
\hline & & Likes & LIKE & $(1-5)$ \\
\hline
\end{tabular}




\section{Confirmatory Factor Analysis}

CFA is used to test a hypothesis that a relationship between observed variables and their underlying latent constructs exists (Suhr, 2020). In this work the CFA (first and second order models) was used to test how well the measured variables represent the number of constructs. The theoretical hypothesis of the CFA $1^{\text {st }}$ order model was constructed based on 11 observed 'variables measuring three latent factors: the consumers' belief about their involvement in food integrity aspects (CINV), the consumers' belief regarding the FBOs' involvement, through online media, in food integrity aspects (PINV) and the consumers' belief about the authorities' involvement, through online media, in food integrity aspects (AINV).

Starting from the basic assumption of factor analysis, that for a collection of observed variables there are underlying factors, the CFA $2^{\text {nd }}$ order was constructed after testing the CFA $1^{\text {st }}$ order, considering three latent factors measuring one mediator factor. The mediator factor was considered to be the involvement (INV) in the online media on food integrity issues, reflected by three main market players: consumer, producer and the authorities.

For the two conceptualized CFA models the hypotheses were: (i) A relationship between the observed variables and their three underlying latent constructs (first order) exists; (ii) A relationship between the latent variable of first order and their underlying latent construct (second order) that would act as a mediator variable exists. The goodness-of-fit model was evaluated to check if the structure fitted the data. The goodness of the model fit was assessed by the following indices: the ratio of the Chi-square to the degrees of freedom $\left(\chi^{2} / \mathrm{df}\right)$, which should be less than 5 , the comparative fit index (CFI) and the adjusted goodness of the fit index (AGFI) which should be higher than 0.8 , the goodness of the fit index (GFI), acceptable if higher than 0.9, the standardized root mean square residual (SRMR), which should be less than 0.1, and the root mean square error of approximation (RMSEA) which should be less than 0.1 (Gaskin, 2016).

\section{Structural Equation Modelling}

SEM was run to test the best fitting model for evaluating the casual relationship between the independent and dependent variables of the conceptual model. Through SEM it was evaluated whether the hypothesized model fits the data observed .

Starting from the idea of the necessity of a public-private partnership in food fraud prevention (Spink et al., 2016b), and adding consumers into the equation, we conceptualized a structure of a common factor model based on: the consumers' belief regarding their involvement in food integrity aspects (CINV), the consumers' belief regarding the FBOs' involvement, through online media, in food integrity aspects (PINV), the consumers' belief regarding the authorities' involvement, through online media, in food integrity aspects (AINV), and the importance of online media when buying food (IOM) (Figure 1). Based on the Risk Information Seeking and Processing model (Griffin et al., 1999), the Theory of Planned Behaviour (Ajzen, 1991) and the Technology Acceptance Model (Davis, 1989), 
other elements as information needed, communication, attitude, perceived usefulness were also considered.

The assumption is that online media is an important tool when buying food (IOM), and using it can influence the involvement of consumers, FBOs, authorities in increasing food integrity (INV). Therefore, the main hypothesis is that the higher the importance of online media when buying food (IOM), the higher the involvement of consumers, FBOs, authorities in supporting food integrity (INV).

The goal of the current research is to find a path that stimulates consumers to be proactive towards food integrity.

The literature on models referring to food integrity in relationship with consumers is scarce, and to the best of our knowledge there is no validated model to show how the involvement in food integrity can be stimulated.

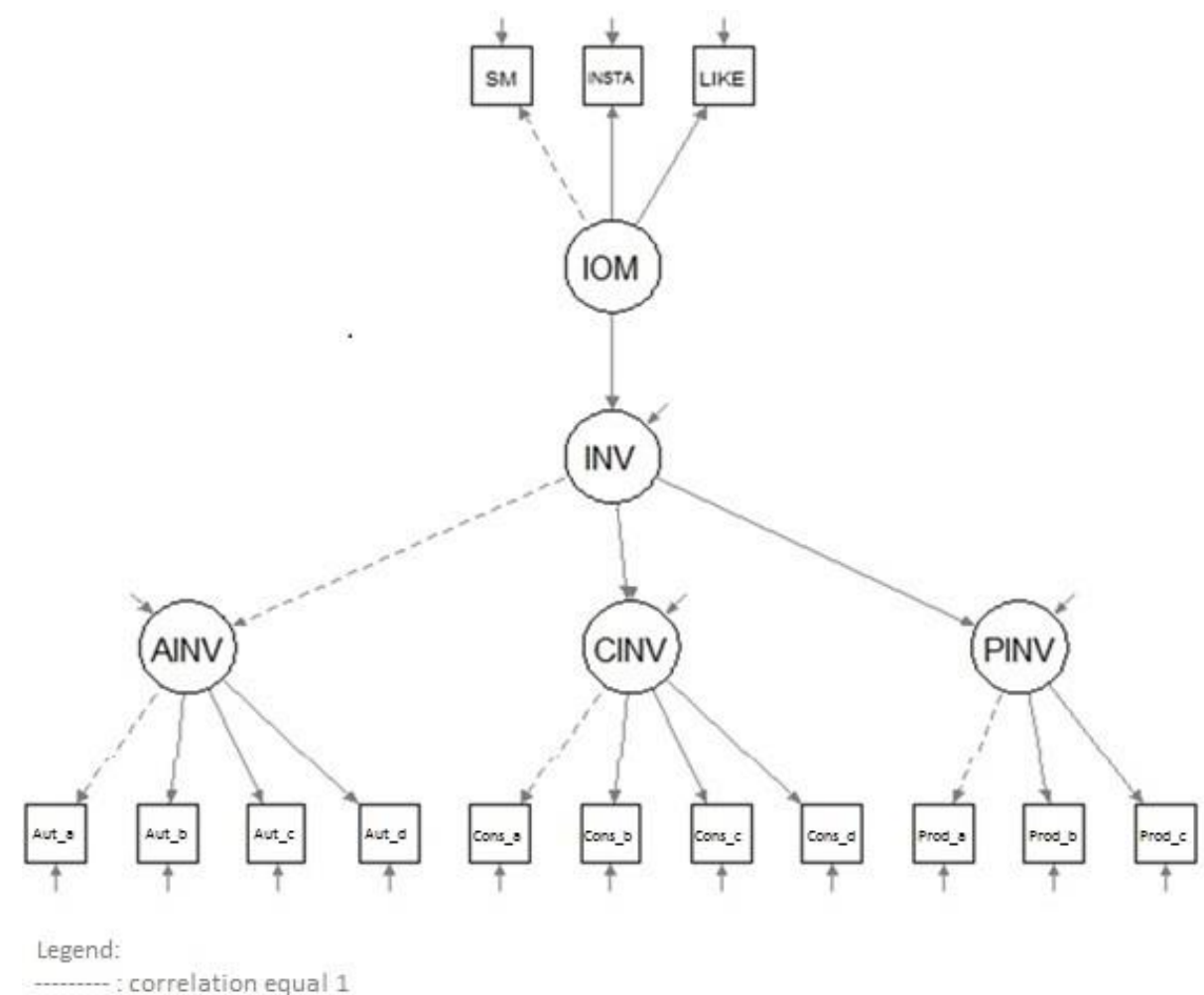

Figure 1. Theoretical construct of the structural equation model. AINV - authorities' involvement; CINV - consumers' involvement; PINV - producers' (FBOs) involvement; IOM - importance of online media when buying food; Aut_a, Aut_b, Aut_c, Aut_d observed variables for AINV; Cons_a, Cons_b, Cons_c, Cons_d - observed variables for CINV; Prod_a, Prod_b, Prod_c - observed variables for PINV; SM, INSTA, LIKE observed variables for IOM. 
The conceptualized general structural equation model consisted of second-order factor model with 11 final items that included three first-order latent variables.

\section{Results and discussion}

\section{Descriptive analysis}

The descriptive analysis shows that of the 190 respondents, 124 were females $(65 \%)$ and 66 males (35\%); their level of education (graduated or on-going) is almost balanced, postgraduate studies (master and $\mathrm{PhD}$ degree) are predominant (35\%), while bachelor's degree accounts for $32 \%$ and high-school/vocational school studies $34 \%$ (Table 2).

Table 2. Demographic profile of consumers $(\mathrm{N}=190)$.

\begin{tabular}{lcc}
\hline Variable & Frequency & $\%$ \\
\hline Gender & & \\
\hline female & 124 & 65.26 \\
male & 66 & 34.74 \\
\hline Age, years old & & \\
\hline$<18$ & 27 & 14.21 \\
$18-24$ & 28 & 14.74 \\
$25-45$ & 87 & 45.79 \\
$46-65$ & 36 & 18.95 \\
$>65$ & 12 & 6.32 \\
\hline Studies carried out or in progress & & \\
\hline High school /vocational school & 64 & 33.68 \\
Faculty & 60 & 31.58 \\
Post-university & 66 & 34.74 \\
\hline
\end{tabular}

Table 3 pointed out the importance given by consumers to food safety, quality and authenticity and their attachment to these concepts when buying food, and the selfreported social responsibility of the consumers towards noncompliant food and the importance of reporting incidents related to food integrity using social media. Food integrity is important for consumers, with a $95.26 \%$ of them being interested in quality and $93.16 \%$ in food safety and authenticity. At the same time, $69 \%$ of consumers appreciate that all the parties involved (authorities, FBOs, consumers) should get involved to eliminate/diminish the inadequate food products on the market. These consumers are considered as being aware that they must be an active part in the food monitoring process. However, more than half of the consumers (62.11\%) do not react (do not notify/ appeal to the responsible institutions to point out deficiencies/ irregularities/ deviations regarding a purchased food item) and only $4.73 \%$ declared that they always react. It should be noticed that none of the consumers over 46 years of age took action against any infringement of food authenticity. This demonstrates that, despite the large interest in authenticity, there is low reactivity of the Romanians against potential food frauds. At the same time, most of the respondents believe that when purchasing a counterfeit/ inauthentic 
food item, this deviation must be reported $(\mathrm{M}=9.02 ; \mathrm{SD}=2.17)$ and consumer complaints can help increase the quality/ safety/ authenticity of foods $(\mathrm{M}=9.12$; $\mathrm{SD}=2.01$ ), as shown in Table 4. This paradoxical situation might be explained by the generational cohort theory which suggests that "individuals who experience the same historical, social, cultural, political and economic events during their comingof-age year share common core values and behaviours over the course of their lives" (Molinillo et al., 2020; Chaney et al., 2017). In this regard, we could explain the attitude of the consumers over 46 ( $0 \%$ complaints), taking into consideration the Romanian context before 1989. Moreover, consumers should be better educated to be proactive and aware of each and every ones` responsibility to safeguard the food chain.

Online media can be used to promote food integrity because most consumers (90\%) use social media and $82.11 \%$ of them are interested in receiving information on food integrity (Table 3).

Table 3. Consumers' awareness of the involvement in food integrity.

\begin{tabular}{lcc}
\hline \multicolumn{1}{c}{ Variable } & Frequency & \% \\
\hline Importance of these factors when buying food & 177 & 93.16 \\
\hline Safety & 181 & 95.26 \\
Quality & 177 & 93.16 \\
authenticity & \multicolumn{1}{c}{} \\
\hline Who should get involved to eliminate /diminish & inadequate (unsafe, & poor quality, \\
falsified, etc.) food products on the market? & 39 & 20.53 \\
\hline authorities & 16 & 8.42 \\
FBOs & 4 & 2.11 \\
consumers & 131 & 68.95 \\
All (authorities, FBOs, consumers) & 9 & \\
\hline Have you called / notified / complained to the & responsible institutions & to report \\
deficiencies / irregularities / deviations regarding a purchased food item? & \\
\hline yes, always & 9 & 4.74 \\
yes, most of the time & 54 & 28.47 \\
sometimes & 118 & 62.11 \\
Not & 156 & \\
\hline Respondents' interest in receiving information on food integrity (\%) & \\
\hline Yes & 34 & 17.89 \\
No & & \\
\hline Use of social media tools (\%) & 171 & 90.00 \\
\hline Yes & 19 & 10.00 \\
\hline No & & \\
\hline
\end{tabular}

The weighted mean scores regarding the consumers' belief about their involvement in food integrity aspects, the FBOs' and authorities' involvement, through online media, and the importance of some factors when buying food are shown in Table 4. 


\section{CFA}

The components' reliability measured through Cronbach's alpha (Table 5) indicate reasonable to good construct reliability for all of the components $(0.77-0.86)$, except PINV (0.60), suggesting good internal consistency between the variables (Ruby et al., 2019).

Table 4. Consumers' self-reported opinion on the need for their involvement in food integrity aspects, and for the need of FBOs' and authorities' involvement, through online media, in food integrity aspects.

\begin{tabular}{|c|c|}
\hline Variable & $\begin{array}{l}\text { Mean (Standard } \\
\text { deviation) }\end{array}$ \\
\hline $\begin{array}{l}\text { Consumers should... } \\
\text { report purchasing of a counterfeit / inauthentic food item }\end{array}$ & $9.02(2.17)$ \\
\hline $\begin{array}{l}\text { complain about the quality / safety/ authenticity of foods, if } \\
\text { needed }\end{array}$ & $9.01(2.01)$ \\
\hline know, learn, learn more about food integrity & $9.09(1.71)$ \\
\hline take part in monitoring/identification of counterfeit food & $7.92(2.80)$ \\
\hline $\begin{array}{l}\text { FBOs should ... } \\
\text { provide consumers with the opportunity to vote/rate their products } \\
\text { based on their own experience - use of an electronic voting system } \\
\text { specify on the label the way of notifying negative aspects online }\end{array}$ & $7.98(2.79)$ \\
\hline be involved in activities/actions to inform/educate consumers & $8.82(2.24)$ \\
\hline $\begin{array}{l}\text { Authorities should ... } \\
\text { provide consumers with the opportunity to report/ notify, online, } \\
\text { negative aspects of food integrity - provide a public platform } \\
\text { use social media to promote food integrity }\end{array}$ & $9.15(2.15)$ \\
\hline $\begin{array}{l}\text { use an IT application to warn consumers that product } \mathrm{X} \text { has } \\
\text { integrity problems / deficiencies }\end{array}$ & $8.67(2.53)$ \\
\hline report, online, the results of the checks carried out at the FBOs & $8.80(2.47)$ \\
\hline \multicolumn{2}{|l|}{ Prioritizing drivers for buying food } \\
\hline Safety & $4.52(0.89)$ \\
\hline Quality & $4.62(0.83)$ \\
\hline Authenticity & $4.59(0.78)$ \\
\hline Social media & $2.62(1.34)$ \\
\hline Instagram & $2.24(1.33)$ \\
\hline Likes/votes, comments of other consumers & $2.80(1.29)$ \\
\hline
\end{tabular}


The measurement model of CFA first order shows a fair relationship between the latent variables and the observed variables, especially for the perceived role of authorities and consumers. The matrix of factor loadings shown in Table 5 demonstrates statistical significance $(p<0.001)$. All of the standardized regression coefficients (factor loadings) have a significant positive effect on their construct with values higher 0.45 .

Table 5. Confirmatory factor analysis (CFA) - first and second order, latent variables.

\begin{tabular}{|c|c|c|c|c|c|c|}
\hline $\begin{array}{c}\text { Latent } \\
\text { variable }\end{array}$ & Code & $\begin{array}{l}\text { Factor } \\
\text { loading }\end{array}$ & SE & $\begin{array}{c}\text { Cronbach's } \\
\text { alpha }\end{array}$ & $\begin{array}{c}\text { CFA } \\
\text { 1st order }\end{array}$ & $\begin{array}{c}\text { CFA } \\
\text { 2nd order }\end{array}$ \\
\hline \multirow[t]{5}{*}{ AINV } & & & & 0.79 & & \\
\hline & Aut_a & 0.734 & & & \multirow{13}{*}{$\begin{array}{l}\text { SRMR }=0.05 \\
3 \\
\chi^{2} / d f=2.42 \\
\text { GFI }=0.920 \\
\text { AGFI }=0.872 \\
\text { CFI }=0.915 \\
\text { RMSEA }=0.0 \\
86 \\
\text { p }<0.001\end{array}$} & \multirow{17}{*}{$\begin{array}{l}\text { SRMR }=0.053 \\
\chi^{2} / d f=2.42 \\
\text { GFI }=0.920 \\
\text { AGFI }=0.872 \\
\text { CFI }=0.915 \\
\text { RMSEA }=0.0 \\
86 \\
\text { p }<0.01\end{array}$} \\
\hline & Aut_b & 0.595 & 0.151 & & & \\
\hline & Aut_c & 0.733 & 0.128 & & & \\
\hline & Aut_d & 0.717 & 0.125 & & & \\
\hline \multirow[t]{5}{*}{ CINV } & & & & 0.77 & & \\
\hline & Cons_a & 0.686 & & & & \\
\hline & Cons_b & 0.718 & 0.118 & & & \\
\hline & Cons_c & 0.786 & 0.104 & & & \\
\hline & Cons_d & 0.53 & 0.157 & & & \\
\hline \multirow[t]{4}{*}{ PINV } & & & & 0.60 & & \\
\hline & Prod_a & 0.482 & & & & \\
\hline & Prod_b & 0.643 & 0.218 & & & \\
\hline & Prod_c & 0.572 & 0.184 & & & \\
\hline \multirow[t]{4}{*}{ INV } & & & & 0.86 & & \\
\hline & AINV & 0.962 & & & & \\
\hline & CINV & 0.711 & 0.117 & & & \\
\hline & PINV & 0.951 & 0.164 & & & \\
\hline
\end{tabular}

SE - standard error; variables: AINV - authorities involvement; CINV - consumers involvement; PINV - producers (FBOs) involvement; INV - involvement of authorities, FBOs, consumers pro food integrity. Aut_a, Aut_b, Aut_c, Aut_d - observed variables for AINV; Cons_a, Cons_b, Cons_c, Cons_d - observed variables for CINV; Prod_a, Prod_b, Prod_c - observed variables for PINV.

However, the measurement model of the second order CFA shows a better relationship between the latent variable of second order and the variables than the CFA first order. For the perceived role of the authorities the latent variable is of first order. The matrix of factor loadings shown in Table 5 demonstrates statistical significance $(\mathrm{p}<0.001)$. All of the standardized regression coefficients (factor loadings) have a significant positive effect on their construct in the CFA second order model. The only value of the adjustment goodness of fit (AGFI) is below, but 
very close, to 0.9 value. The other parameters indicating the model fit are in good agreement with the experimental values and demonstrate the adequacy of the selected CFA models.

The correlations between the constructs are shown in the variance-covariance matrix of the latent factors in Table 6. All three correlations (AINV is correlated with CINV; AINV is correlated with PINV, and CINV is correlated with PINV) are significant $(\mathrm{p}<0.001)$. Since the most fundamental part of a CFA model is assuming that covariances among items are due to a single common factor, this strong correlation supports the theoretical assumption of a CFA second order model.

Table 6. Confirmatory factor analysis - first order, covariances.

\begin{tabular}{lcccc}
\hline & & Covariance & SE & p-value \\
\hline AINV & & & & \\
& CINV & 0.684 & 0.294 & $<0.001$ \\
& PINV & 0.915 & 0.392 & $<0.001$ \\
CINV & & & & \\
& PINV & 0.676 & 0.314 & $<0.001$ \\
\hline
\end{tabular}

SE - standard error; Variables AINV - authorities involvement; CINV - consumers involvement; PINV - producer involvement; INV - involvement of authorities, FBOs, and pro food integrity consumers

In conclusion, by testing the model structure through the CFAs of second order, the hypothesized structure fits the data well was accepted. At the same time, we noted that only three observed variables Prod_a, Prod_b, Prod_c had a weaker contribution to describing the factor related with the perception of FBOs. In this case, the perception of consumers regarding the FBOs' responsibility and their involvement without controlling if a consumer is also an FBO in a specific area of the food chain was measured. Therefore, these results of lower loadings do not necessarily indicate that the indicators are conceptually more distant from the supposed latent variable, and therefore should not question the validity of the measurement model and the latent variable for this model, because the indicators measure the same thing and the model fit indicators are good.

\section{SEM}

The SEM analysis was conducted in $R$, using lavaan package for data analysis and semPlot package for graphics. After the model was designed, the SEM function was used and the results obtained are shown in Table 7 and 8, while Figure 2 was constructed with the semPaths function, using lisrel style and tree2 layout. Figure 2 also synthetises the results from Table 7 and 8 .

The SEM measurement model shows a good relationship between the latent variables and the observed variables. The matrix of factor loadings shown in Table 
7 are statistically significant $(\mathrm{p}<0.001)$ at $\beta=0.96$ for AINV, 0.71 for CINV and 0.95 for PINV, and the hypotheses $\mathrm{H} 2, \mathrm{H} 3$ and $\mathrm{H} 4$ are validated. All of the standardized regression coefficients (factor loadings) have a significant positive effect on their construct and values higher than 0.480, which demonstrates construct validity (Singh et al., 2018).

To confirm the validity of the proposed hypotheses, the $\beta$-coefficients and their significance to the model was tested. $\mathrm{H} 2$, which presumes that a relationship between INV and AINV exists, has the highest path coefficient (0.961) and is significant at $\mathrm{p}<0.001$. The same positive correlation was demonstrated for hypotheses $\mathrm{H} 3$ and $\mathrm{H} 4$.

Table 7. Structural Equation Model, latent variables.

\begin{tabular}{ccccc}
\hline Latent variable & $\begin{array}{c}\text { Observed } \\
\text { variable }\end{array}$ & $\begin{array}{c}\text { Standardized } \\
\text { factor loadings }\end{array}$ & $\begin{array}{c}\text { Standard } \\
\text { Error }\end{array}$ & p-value \\
\hline AINV & Aut_a & 0.726 & & $<0.001$ \\
& Aut_b & 0.599 & 0.154 & $<0.001$ \\
& Aut_c & 0.744 & 0.131 & $<0.001$ \\
& Aut_d & 0.713 & 0.127 & $<0.001$ \\
CINV & Cons_a & 0.686 & & $<0.001$ \\
& Cons_b & 0.717 & 0.118 & $<0.001$ \\
& Cons_c & 0.785 & 0.104 & $<0.001$ \\
& Cons_d & 0.533 & 0.157 & $<0.001$ \\
PINV & Prod_a & 0.489 & & $<0.001$ \\
& Prod_b & 0.644 & 0.213 & $<0.001$ \\
& Prod_c & 0.568 & 0.179 & $<0.001$ \\
IOM & SM & 0.775 & & $<0.001$ \\
& INSTA & 0.795 & 0.115 & $<0.001$ \\
& LIKE & 0.706 & 0.102 & $<0.001$ \\
\hline
\end{tabular}

AINV - authorities involvement; CINV - consumers involvement; PINV - producers (FBOs) involvement; INV - involvement of authorities, FBOs, and consumers in food integrity; IOM Importance of Internet and online media.

IOM has a direct positive impact on INV. Since p $<0.005$ (see Table 8) and is significant at $95 \%$ confidence and $\beta(0.265)$ is positive, $\mathrm{H} 1$ is supported. 


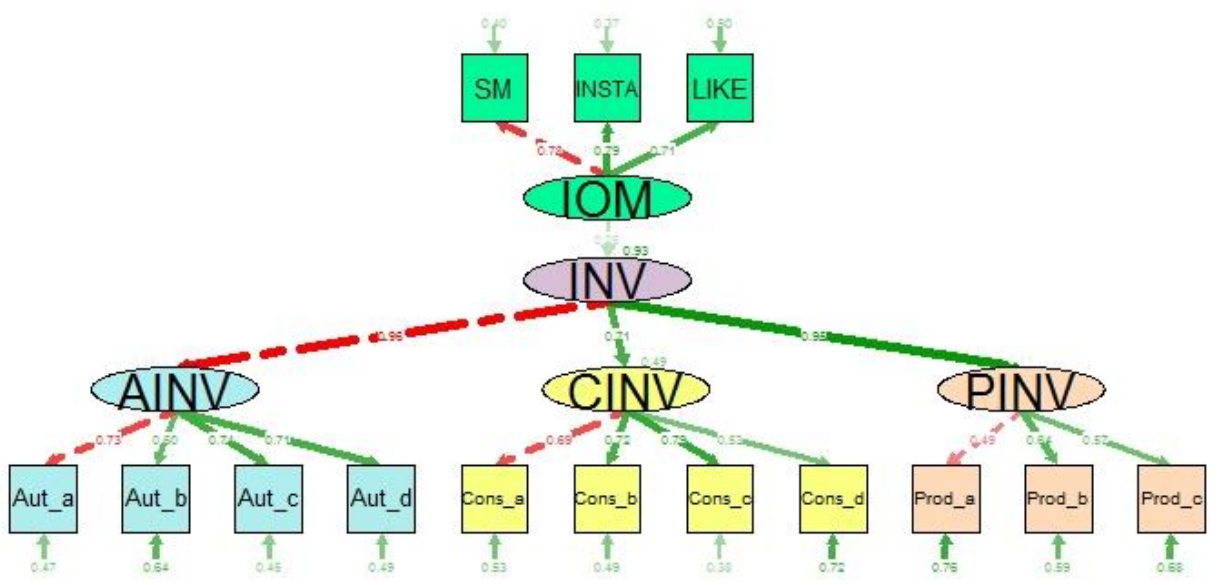

Figure 2. General structural equation model. AINV - authorities' involvement. CINV consumers' involvement; PINV - producers (FBOs)' involvement; IOM - the importance of online media when buying food; Aut_a, Aut_b, Aut_c, Aut_d - observed variables for AINV; Cons_a, Cons_b, Cons_c, Cons_d - observed variables for CINV; Prod_a, Prod_b, Prod_c - observed variables for PINV; SM, INSTA, LIKE -observed variables for IOM.

Table 8. Hypothesis testing.

\begin{tabular}{cccccc}
\hline $\begin{array}{c}\text { Hypothesis } \\
\text { testing }\end{array}$ & & $\begin{array}{c}\text { Path coefficient } \\
(\boldsymbol{\beta})\end{array}$ & SE & p-value & Decision \\
\hline INV & AINV & 0.961 & & $<0.001$ & H2 supported \\
& CINV & 0.714 & 0.119 & $<0.001$ & H3 supported \\
& PINV & 0.946 & 0.165 & $<0.001$ & H4 supported \\
IOM & INV & 0.265 & 0.132 & $<0.004$ & H1 supported \\
\hline
\end{tabular}

SE - standard error; H1, H2, H3 - research hypothesis; AINV - authorities involvement; CINV consumers involvement; PINV - producers (FBOs) involvement; INV - involvement of authorities, FBOs, and consumers in food integrity; IOM - Importance of Internet and online media.

\section{Model fit measurement}

The values obtained for the model fit measurement of the SEM model (Table 9) show a plausible model, however some of the model fit parameters (GFI) are close but not above the threshold limit. This could have been influenced by the relatively small sample size considered in the current research.

There is need for the development of resourceful tools in order to detect inadequate food products on the market, and as data show, one way to do that is using online media. This is in line with Manning and Soon (2019) who stated that "the media plays an increasingly important role in providing the evidence that underpins food fraud governance, influencing the behaviour, attitudes of government, FBOs and consumers". 
Table 9. SEM model fit $(\mathrm{N}=190)$.

\begin{tabular}{ccc}
\hline Parameters & $\begin{array}{c}\text { Thresholds for } \\
\text { acceptable fit }\end{array}$ & SEM \\
\hline $\mathrm{df}$ & & 73 \\
$\chi^{2}$ & $<3.00-5.00$ & 174.53 \\
$\chi^{2} / d f$ & $>0.90$ & 2.39 \\
$\mathrm{GFI}$ & $>0.80$ & 0.893 \\
$\mathrm{AGFI}$ & & 0.846 \\
$\mathrm{p}-\mathrm{value}$ & $>0.80$ & $<0.000$ \\
CFI & $<0.1$ (moderate) & 0.888 \\
RMSEA & $<0.09$ & 0.086 \\
SRMR & & 0.066 \\
\hline
\end{tabular}

$\mathrm{df}$ - degrees of freedom; $\chi^{2}$ - Chi-Square value; $\chi 2 / d f$ - relative Chi-Square value; GFI - goodnessof-fit; AGFI - adjusted goodness-of-fit statistic; CFI - m; RMSEA - root mean square error of approximation; SRMR - standardised root mean square residual

Therefore, it is necessary to involve more consumers, use the potential of the social media, increase visibility and cooperation between all stakeholders. In order to obtain a reaction, the consumers' attitude emerges as a key factor for a suitable plan on food fraud abatement. Social Media is a great opportunity for intervention, its possibilities seems limitless, and consumers have become more technologically savvy and capable of using smart technology (Adapa et al., 2020). While social media could be a strong tool for consumer communication and education, one must keep in mind that it could also be the primary tool for spreading misinformation.

Given the limited capacity of the Romanian authorities and most of the FBOs to use the online media in their relations with consumers in providing complaints or for information or education, we appreciate that this study could be useful through the implementation of the items measured. Strengthening the online collaboration between authorities, FBOs, NGOs, academia and consumers can be a sustainable solution in the long run that requires more attention in future research.

This research should be regarded as a pioneer study on modelling food integrity involvement in relationship with consumers and online media as a process monitoring tool. The use of online media is a relatively new phenomenon and no attempt has been made so far to model the participation in online media with consumers`expectations and with the authorities' and FBOs' involvement.

While now the model can raise awareness on the issue of the consumers' involvement in food integrity through online media, later on it can be improved. 


\section{Other issues related to the study}

\section{Sources of errors in the questionnaire}

Distortion factors as (i) unassisted completing; (ii) the fact that respondents under the age of 18 might not understand all the terms (e.g. authenticity, food integrity); (iii) the fact that some respondents appreciated that TV and radio channels are included in the category of social media, may constitute sources of errors in our survey.

\section{Limits of investigation}

The limitation of this research is related to the nature of the survey sample. Although the sample size is small for statistical inference, we consider that the number of respondents (190) might be sufficient for the proposed SEM model. In literature, there is a widely-cited rule of thumb, the "rule of 10". Although it isn't empirically supported, starting from Nunnally (1978) it is largely suggested that in multivariate analyses at least 10 times as many subjects (outcomes) as predictors are used. According to this, for the 14 items of the latent variables used, the sample of 190 respondents can be considered a good size. The small sample size is characteristic for the self-administered surveys (Roman et al., 2017) and this study belongs to the same category.

\section{Further research}

A new research could be conducted in order to improve/ develop the proposed model by considering other new predictors. To the author's knowledge, this paper is the first one to examine the possibility of involving consumers in monitoring food chain integrity and to analyse this topic through SEM.

Further investigation could be focused on extending the current results or on specific categories of consumers and peculiar social media channels.

\section{Conclusions}

In Romania, besides authorities and food business operators, consumers could be involved in managing food integrity. If involvement is performed in a coherent manner, it might represent a significant contribution to the effort of eliminating inadequate food products from the market. Almost a half of the consumers prove to be interested in actively participating in monitoring food integrity and periodically receiving information on this subject through online media. In our relational approach, we obtained the statistical evidence for the existence of connections between consumers, FBOs, authorities and the use of social media to monitor food integrity. Consumers believe that social media can be a channel for communication with the authorities and FBOs. Exploited in conjunction with conventional practices, social media could represent both an educational and management tool in the domain of food integrity. The Romanian authorities, in particular, could develop their administrative capacity (infrastructure, tools, and human resources) to be able to transform consumers in their allies in fighting against food fraud and 
noncompliant food in general, and to share with them the responsibility of food integrity.

\section{References}

Adapa, S., Fazal-e-Hasan, S.M., Makam, S.B., Azeem, M.M., Mortimer, G. 2020. Examining the antecedents and consequences of perceived shopping value through smart retail technology. Journal of Retailing and Consumer Services, 52, 101901.

Afonso, A., Garcia Matas, R., Maggiore, A., Merten, C., Yin, A., Robinson, T. 2019. EFSA Supporting Publications, 16(8), 1704E.

Ajzen, I. 1991. The theory of planned behavior. Organizational Behavior and Human Decision Processes, 50(2), 179-211

Ali, M.H., Suleiman, N. 2018. Eleven shades of food integrity: A halal supply chain perspective. Trends in Food Science Technology, 71, 216-224.

Ali, M.H., Tan, K.H., Ismail, M. D. 2017. A supply chain integrity framework for halal food. British Food Journal, 119(1), 20-38.

Borda, D., Mihalache, A., Dumitrașcu, L., Gafițianu, D., Nicolau, A.I. 2020. Romanian consumers' food safety knowledge, awareness on certified labelled food and trust in information sources. Food Control, 107544.

Bradshaw, T. 2012. McDonald's Twitter campaign hijacked. The Financial Times, New York.

Byrd-Bredbenner, C., Cohn, M.N., Farber, J.M., Harris, L.J., Roberts, T., Salin, V., ... \& Sperber, W.H. 2015. Food safety considerations for innovative nutrition solutions. Annals of the New York Academy of Sciences, 1347(1), 29-44.

Cattini, C. 2016. Food fraud costs the global food industry $\$ 10-15$ billion annually https://www.ifis.org/blog/global-food-fraud, posted on 04.04.2016

Chapman, B., Raymond, B., Powell, D. 2014. Potential of social media as a tool to combat food borne illness. Perspectives in Public Health, 134(4), 225-230.

Chaney, D., Touzani, M., Slimane, K.B. 2017. Marketing to the (new) generations: summary and perspectives. Journal of Strategic Marketing, 25(3), 179-189.

Danezis, G.P., Tsagkaris, A.S., Camin, F., Brusic, V., Georgiou, C.A., 2016. Food authentication: Techniques, trends \& emerging approaches, Trends in Analytical Chemistry, 85, Part A, 123-132.

Davis, F.D. 1989. Perceived usefulness, perceived ease of use and user acceptance of information technology. MIS Quarterly, 13(3), 319-339.

Davis, R., Sheriff, K., Owen, K. 2019. Conceptualising and measuring consumer authenticity online. Journal of Retailing and Consumer Services, 47, 17-31.

ECDC. 2016. Social media strategy development - A guide to using social media for public health communication. Stockholm. https://www.ecdc.europa.eu

Elliott, C.T. 2012. Food integrity and traceability. Centre for assured, safe and traceable food (ASSET). Trends in Food Science and Technology, 28, 61.

Ellis, D., Muhamadali, H., Allen, D., Elliot, C., Goodacre, R. 2016. A flavour of omics approaches for the detection of food fraud. Current Opinion in Food Science, 10, 7-15.

Europol, 2019. Over $€ 100$ million worth of fake food and drinks seized in latest Europol Interpol operation https://www.europol.europa.eu/newsroom/news/over-\%E2\%82\%AC100- 
million-worth-of-fake-food-and-drinks-seized-in-latest-europol-interpol-operation (accessed 1.10.2020)

Gaskin, J. 2016. Confirmatory factor analysis, Gaskination's statWiki. Retrieved from statwiki.kolobkreations.com.

Goyal, S. 2020. Future shock: 25 food trends post Covid-19. Marketing \& Advertising News. https://brandequity.economictimes.indiatimes.com/news/marketing/futureshock-25-food-trends-post-covid-19/75590741.

Griffin, R., Dunwoody, S., Neuwirth, K. 1999. Proposed model of the relationship of risk information seeking and processing to the development of preventive behaviors. Environmental Research, 80(2), S230-S245.

Hamshaw, R.J.T., Barnett, J., Lucas, J.S. 2018. Tweeting and eating: The effect of links and likes on food-hypersensitive consumers' perceptions of tweets. Frontiers in Public Health, 6, 118.

King, T., Cole, M., Farber, J.M., Eisenbrand, G., Zabaras, D., Fox, E. M., Hill, J.P. 2017. Food safety for food security: Relationship between global megatrends and developments in food safety. Trends in Food Science and Technology, 68, 160-175.

Kline, R.B. 2011. Principles and practice of structural equation modeling. Third edition, Guilford Press.

Kuttschreuter, M., Hilverda, F. 2019. "Listen, did you hear...?” A structural equation model explaining online information sharing on the risks of nanotechnology in food. Food Quality and Preference, 76, 118-132.

Lobb, A. 2005. Consumer trust, risk and food safety: A review. Food Economics - Acta Agriculturae Scandinavica, Section C, 2(1), 3-12.

Ma, J., Almanza, B., Ghiselli, R., Vorvoreanu, M., Sydnor, S. 2017. Food safety information on the internet: Consumer media preferences. Food Protection Trends, 37(4), 247-255

Macready, A., Hieke, S., Klimczuk-Kochanska, M., Szumial, S., Vranken, L., Grunert, K. 2020. Consumer trust in the food value chain and its impact on consumer confidence: A model for assessing consumer trust and evidence from a 5-country study in Europe. Food Policy, 92, 101880.

Martini, A., Massa, S., Testa, S. 2014. Customer co-creation projects and social media: The case of Barilla of Italy. Business Horizons, 57(3), 425-434.

Mangold, W.G., Faulds, D.J. 2009. Social media: The new hybrid element of the promotion mix. Business Horizons, 52(4), 357-365.

Manning, L. 2016. Food fraud: Policy and food chain. Current Opinion in Food Science, 10, 16-21.

Manning, L. 2017. Food integrity. British Food Journal, 119(1), 2-6.

Manning, L., Soon, J.M. 2019. Food fraud vulnerability assessment: Reliable data sources and effective assessment approaches. Trends in Food Science \&Technology, 91, 159168.

Molinillo, S., Vidal-Branco, M., Japutra, A. 2020. Understanding the drivers of organic foods purchasing of millennials: Evidence from Brazil and Spain. Journal of Retailing and Consumer Services, 52, 101926.

Nunnally, J.C. 1978. Psychometric theory (2nd Ed.). New York: McGraw-Hill. 
Roberts, S. 2020. Viral marketing examples: 6 great campaigns and their effects. Marketing Viral. (https://www.cyberclick.net/numericalblogen/viral-marketing-examples-6-greatcampaigns-and-their-effects).

Roman, S., Sánchez-Siles, L.M., Siegrist, M. 2017. The importance of food naturalness for consumers: Results of a systematic review. Trends in Food Science \& Technology, 67, 44-57.

Ruby, G.E., Ungku Zainal Abidin, U.F., Lihan, S., Jambari, N.N., Radu, S. 2019. A cross sectional study on food safety knowledge among adult consumers. Food Control, 99, 98-105.

Rutsaert, P., Pieniak, Z., Regan, Á., McConnon, Á., Kuttschreuter, M. Ô., Lores, M., Lozano N., Guzzon A., Santare D., Verbeke W. 2014. Social media as a useful tool in food risk and benefit communication? A strategic orientation approach. Food Policy, 46, 84-93.

SGG (Secretariatul General al Guvernului României), 2015. Analiză privind integritatea alimentelor în România. Raport Proiect Pilot EIR.

http://sgg.gov.ro/docs/File/UPP/doc/analiza_impact/Analiza\%20privind\%20integritatea \%20alimentelor\%20in\%20Romania.pdf (accessed at 14.11.2020).

Singh, V., Kumar, A., Singh, T. 2018. Impact of TQM on organisational performance: The case of Indian manufacturing and service industry. Operations Research Perspectives, 5, 199-217.

Soon, J.M., Krzyzaniak, S.C., Shuttlewood, Z., Smith, M., Jack, L. 2019. Food fraud vulnerability assessment tools used in food industry. Food Control, 101, 225-232.

Spink, J., Keogh, J., Moyer, D. 2019. International survey of food fraud and related terminology: preliminary results and discussion. Journal of Food Science, 84(10), 2705-2718.

Spink, J., Moyer, D.C., Speier-Pero, C. 2016a. Introducing the food fraud initial screening model (FFIS). Food Control, 69, 306-314.

Spink, J., Moyer, D.C., Whelan, P. 2016b. The role of the public private partnership in Food Fraud prevention-includes implementing the strategy. Current Opinion in Food Science, 10, 68-75.

Suhr, S. 2020. Exploratory or confirmatory factor analysis. www. support.sas.com/resources/papers/proceedings/proceedings/sugi31/200-31.pdf (accessed on may 2020).

Van Der Lans, R., Van Bruggen, G., Eliashberg, J., Wierenga, B. 2010. A viral branching model for predicting the spread of electronic word of mouth. Marketing Science, 29, 348-365.

Wang, W., Zhou, X., Suo, Y., Deng, X., Cheng, M., Shi, C., Shi, X. 2017. Prevalence, serotype diversity, biofilm-forming ability and eradication of Listeria monocytogenes isolated from diverse foods in Shanghai, China. Food Control, 73, 1068-1073. 